\author{
Andrzej Sobczak*
}

\title{
METAMODEL ARCHITEKTURY KORPORACYJNEJ PAŃSTWA
}

Streszczenie. W celu efektywnego przeprowadzenia cyfrowej transformacji państwa niezbędne jest zastosowanie odpowiedniego aparatu metodycznego. Jednym z narzędzi wspierających przeprowadzenie tej transformacji może być architektura korporacyjna państwa. W artykule podjęto próbę zdefiniowania tego pojęcia oraz zaprezentowano autorski metamodel pozwalający na jednolite stosowanie pojęć używanych na diagramach architektonicznych. Dzięki temu możliwe jest zbudowanie spójnego opisu państwa w ujęciu architektonicznym.

Słowa kluczowe: architektura korporacyjna, architektura korporacyjna państwa, metamodel architektoniczny, modele architektoniczne, metamodel architektury korporacyjnej państwa.

\section{WSTĘP}

Cyfrowa transformacja państwa, rozumiana jako szczególny rodzaj zmiany organizacyjnej, której efektem będzie głęboka integracja technologii cyfrowych i procesów biznesowych, ma prowadzić do powstania nowego modelu funkcjonowania całego państwa, którego istotnym elementem są zintegrowane i sprawnie działające rozwiązania informatyczne (Day-Yang, Shou-Wei, Tzu-Chuan 2011: 1728-1742). Podejmowane w Polsce próby takiej transformacji mają najczęściej charakter cząstkowy oraz nieskoordynowany. Powoduje to, że wdrażane są rozwiązania (zarówno technologiczne, jak i organizacyjne) ,optymalne lokalnie", tzn. odnoszące się do konkretnego problemu/zagadnienia na poziomie pojedynczego urzędu, ale nieprzyczyniające się do faktycznej poprawy funkcjonowania całego państwa.

Już kilka lat temu przedstawiciele Ministerstwa Administracji i Cyfryzacji wskazywali, że dotychczasowy model informatyzacji ,doprowadził do powstawania rozwiązań silosowych, dziedzinowych o zasięgu maksymalnie jednego resortu”. Ponadto zaznaczali oni, że „brakuje powiązań pomiędzy dziedzinowymi systemami poszczególnych resortów" (MSWiA 2011: 4). Powoduje to, iż „tracony jest w ten sposób efekt synergii możliwy do uzyskania dzięki modernizacji procesów administracyjnych, szczególnie realizowanych horyzontalnie, w poprzek wertykalnych systemów dziedzinowych" (MSWiA 2011: 4).

\footnotetext{
*Szkoła Główna Handlowa w Warszawie, Zakład Zarządzania Informatyką, sobczak@sgh.waw.pl
} 
Alternatywnym podejściem (nakierowanym na znalezienie i realizację „optimum globalnego", tj. wdrożenie rozwiązań zwiększających efektywność funkcjonowania całego państwa) jest wykorzystanie ujęcia architektonicznego (określanego mianem architektury korporacyjnej państwa), które zakłada holistyczne postrzeganie państwa i przedsięwzięć realizowanych w jego ramach.

Celem niniejszego artykułu jest próba zidentyfikowania kluczowych aspektów budowy architektury korporacyjnej państwa i ujęcia ich w formie definicji tego pojęcia oraz wskazanie w jaki sposób można przeprowadzić te prace na bazie dedykowanego metamodelu architektonicznego.

Przyjęcie powyższych celów narzuciło określoną konstrukcję artykułu: punkt drugi zawiera próbę definicji architektury korporacyjnej państwa; w punkcie trzecim omówiono koncepcję modeli i metamodeli architektonicznych; w punkcie czwartym przedstawiono strukturę pilotażowej wersji autorskiego metamodelu architektury korporacyjnej państwa; artykuł kończy podsumowanie i wskazanie kierunków dalszych prac badawczych.

\section{PRÓBA DEFINICJI ARCHITEKTURY KORPORACYJNEJ PAŃSTWA}

Architektura korporacyjna państwa może być rozumiana jako szczególny przypadek architektury korporacyjnej - po pierwsze, odniesiony do administracji publicznej, po drugie, obejmujący wszystkie (lub prawie wszystkie) podmioty administracji publicznej - zarówno rządowe, jak i samorządowe.

Analogicznie do architektury korporacyjnej w przypadku architektury korporacyjnej państwa można przyjąć, że ma ona cztery znaczenia: atrybutowe, rzeczowe, czynnościowe oraz obszaru badawczego (Sobczak 2015: 220-245).

W ujęciu atrybutowym architektura korporacyjna państwa może być rozumiana jako zbiór właściwości administracji publicznej rozpatrywanej jako całość (i relacji między składowymi tej administracji), które są niezbędne do zapewnienia realizacji celów strategicznych państwa (zawartych np. w dokumentach strategicznych, a w przypadku ich braku - aktach prawnych, w szczególności w konstytucji). W tym ujęciu określenie ,architektura korporacyjna państwa” ma więc zastosowanie do każdego kraju, przy czym architektura jednego kraju może być lepsza, a drugiego gorsza. Jakość architektury korporacyjnej państwa może być rozpatrywana w kontekście efektywności świadczenia usług publicznych (nie tylko drogą on-line) na rzecz obywateli/podmiotów funkcjonujących na terenie danego kraju.

Architekturę korporacyjną państwa w ujęciu rzeczowym można zdefiniować jako formalną reprezentację (dokumentację) głównych składowych państwa (struktur organizacyjnych, usług i procesów biznesowych, ewidencji, rejestrów 
i baz danych, kluczowych aplikacji oraz komponentów infrastrukturalnych). Ze względu na bardzo dużą złożoność administracji publicznej nie ma możliwości opisania wszystkich składowych na tym samym poziomie szczegółowości. Dlatego istotne jest opracowanie kaskady architektonicznej, w ramach której architektury niższego szczebla muszą być spójne $\mathrm{z}$ architekturą wyższego szczebla. $\mathrm{Na}$ kaskadę tę składa się architektura strategiczna obejmująca swoim zakresem całe państwo, architektury poszczególnych jednostek administracyjnych (lub grup jednostek, np. resortów), architektury poszczególnych kluczowych systemów informatycznych.

Architektura korporacyjna państwa powinna przedstawiać zarówno obecny sposób działania administracji publicznej, jej stan docelowy (np. na koniec cyfrowej transformacji), jak również stany pośrednie (w określonych etapach transformacji).

W ujęciu czynnościowym architekturę korporacyjną państwa można zdefiniować jako narzędzie do operacjonalizacji celów strategicznych państwa (są one doprecyzowywane, uszczegółowiane, konkretyzowane, pozbawiane wszelkich wyrażeń niejednoznacznych, nieprecyzyjnych, emocjonalnych; ponadto dookreśleniu ulega rezultat/korzyść oraz sposoby i warunki realizacji tych celów). Oznacza to, że koncentruje się ona na: kluczowych dla państwa przedsięwzięciach (przy czym należy zauważyć, że przedsięwzięcia te nie powinny być jedynie postrzegane poprzez pryzmat IT - w szczególności mogą one mieć charakter legislacyjno-organizacyjno-informatyczny), ich zmianach w czasie oraz relacjach pomiędzy nimi - obejmuje zarówno modele architektoniczne na wysokim poziomie ogólności (w tym sposoby ich wytwarzania), jak i mechanizmy nadzoru architektonicznego (por. Rysunek 1).

Nadzór i koordynacja za pomocą architektury strategicznej

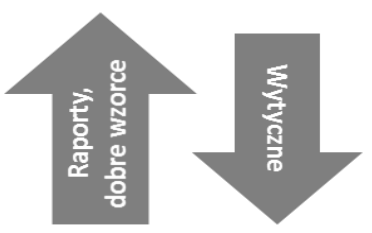

Przedsięwzięcie „A"

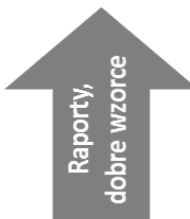

Przedsięwzięcie „B”

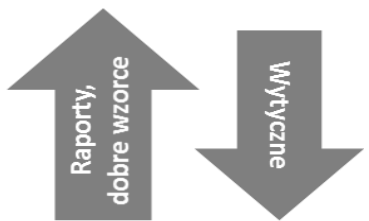

Przedsięwzięcie „C”

Rysunek 1. Koordynacyjny charakter architektury korporacyjnej państwa Źródło: opracowanie własne. 
W szczególności, ale nie wyłącznie, oznacza to, że architektura korporacyjna państwa może być na poziomie merytorycznym wykorzystana do koordynacji cyfrowej transformacji państwa. Przy czym przez transformację tę rozumie się działania mające doprowadzić do powstania nowego modelu funkcjonowania państwa, którego istotną częścią będą odpowiednio wdrożone rozwiązania informatyczne, będące podstawą świadczenia elektronicznych usług publicznych. Ich wykorzystanie spowoduje radykalne zwiększenie poprawy wydajności i jakości dostarczanych przez państwo usług.

Ponadto J. Lapalme wskazuje, że podejście architektoniczne może być zastosowane przy projektowaniu wszystkich aspektów funkcjonowania dowolnej organizacji, a także podczas doskonalenia relacji organizacji ze środowiskiem, w którym ona funkcjonuje. Według niego architektura korporacyjna jest więc „środkiem do uzyskania innowacji i zrównoważonego rozwoju organizacji" (Lapalme 2011: 37-43). Analogicznie również architektura korporacyjna państwa umożliwia zaprojektowanie i doskonalenie zasad funkcjonowania administracji publicznej (rozpatrywanej całościowo - tj. w ujęciu systemowym) - zarówno jej procesów wewnętrznych, jak i usług świadczonych kanałami tradycyjnymi i elektronicznymi przez administrację na rzecz podmiotów zewnętrznych.

Jeżeli chodzi o rozpatrywanie architektury korporacyjnej państwa jako obszaru badawczego, niezbędne jest podkreślenie jej interdyscyplinarnego charakteru. Łączy ona bowiem zagadnienia dotyczące: zarządzania, cybernetyki, informatyki, wizualizacji naukowej, a także prawa i administracji.

\section{POJĘCIE MODELU I METAMODELU ARCHITEKTONICZNEGO}

Jak pisze J. Kisielnicki, termin „model” ma szeroki zakres znaczeniowy (Kisielnicki 1993: 93). Na potrzeby rozważań podjętych w niniejszym artykule przyjęta została definicja zaproponowana przez J. Gutenbauma. Model „rozumiany jest jako uproszczona - (...) umyślnie i celowo - reprezentacja (...) badanego obiektu. Stanowi on pewien substrat rzeczywistości. Jest on pozbawiony wielu szczegółów i cech nieistotnych z punktu widzenia celów modelowania" (Gutenbaum 2003: 11). W niniejszym opracowaniu przyjęto, że badanym obiektem jest państwo lub jego istotny fragment.

S. Kaisler, F. Armour oraz M. Valivullah wskazują, że modelowanie jest jednym z trzech kluczowych obszarów prac w zakresie architektury korporacyjnej (oprócz nadzoru nad stosowaniem architektury), które pozwala ją opisać oraz zrozumieć (Kaisler, Armour, Valivullah 2005: 1203).

Należy odnieść się tutaj do wskazywanej w punkcie 2. artykułu wieloznaczności terminu ,architektura korporacyjna państwa”. W ujęciu atrybutowym mo- 
del będzie opisywał tę architekturę, natomiast w ujęciu rzeczowym model będzie stanowił tę architekturę (czyli w tym podejściu architektura korporacyjna składa się z modeli). Rolę tego ostatniego ujęcia architektury korporacyjnej podkreślają m.in. G. Khoury, S. Simoff i J. Debenham. Według nich ma ona postać holistycznego zbioru modeli, które pomagają zarządzać zmianami na poziomie zarówno IT, jak i biznesowym (Khoury, Simoff, Debenham 2005: 41-46).

Modele architektoniczne są sporządzane w różnych językach (np. ArchiMate, UML, BPMN) i na różnym poziomie szczegółowości (strategicznym, segmentów i potencjału).

Współdzielenie wiedzy architektonicznej pomiędzy różnymi organizacjami lub nawet $w$ ramach jednej organizacji (pomiędzy jej poszczególnymi jednostkami składowymi) stanowi duże wyzwanie (Liang, Jansen, Avgeriou 2009: 226). Przede wszystkim stosowana terminologia, podejście do modelowania, poziom szczegółowości tworzonych modeli nie są jednoznaczne. Powoduje to, że pojawiają się trudności z zachowaniem spójności podczas tworzenia modeli architektury korporacyjnej (im większa, bardziej złożona jest organizacja tym większe są wyzwania w tym obszarze). Rozwiązaniem tej sytuacji jest opracowanie metamodeli architektonicznych stanowiących podstawę do komunikacji i wymiany wiedzy architektonicznej, przy czym sam metamodel jest definiowany jako jawny model konstruowania modeli dziedzinowych. Wyjaśnia on znaczenie konstrukcji użytych do budowy modeli dziedzinowych i związków między tymi konstrukcjami (OMG 2004: 193).

Metamodel może być zdefiniowany jako trójka (Sobczak 2013: 161)

$$
\mathrm{M}=(\mathrm{C}, \mathrm{T}, \mathrm{R})
$$

gdzie:

$\mathrm{C}-$ jest zbiorem konceptów;

$\mathrm{T}$ - jest zbiorem typów relacji; przykładowe typy to: asocjacja, realizacja, użycie, przypisanie, kompozycja, dostęp;

$\mathrm{R} \subseteq \mathrm{C} \times \mathrm{C} \times \mathrm{T}$ - jest zbiorem relacji; bardziej precyzyjnie: element $\left(\mathrm{c}_{1}, \mathrm{c}_{2}, \mathrm{t}\right)$ $\in \mathrm{R}$ wyraża fakt, że koncept $\mathrm{c}_{1}$ jest $\mathrm{w}$ relacji typu t do konceptu $\mathrm{c}_{2}$.

Metamodel określa więc semantykę i sposób użycia konceptów występujących na modelach. Nazywany jest on także często modelem modelu.

Dzięki stworzonemu metamodelowi możliwe jest zapewnienie wspólnego rozumienia pojęć pomiędzy interesariuszami zaangażowanymi w prace architektoniczne. G. Khoury, S. Simoff oraz J. Debenham zauważają bowiem, że model jest instancją (wystąpieniem) metamodelu (Khoury, Simoff, Debenham 2005: 45-46), czyli od strony formalnej model może zostać zdefiniowany na bazie metamodelu jako czwórka: 


$$
\mathrm{A}=\left(\mathrm{E}, \mathrm{T}^{*}, \mathrm{Q}, \mathrm{F}_{\mathrm{c}}\right)
$$

gdzie:

$\mathrm{E}-$ jest zbiorem elementów modelu;

$\mathrm{T}^{*}$ - jest zbiorem typów relacji (takich samych typów relacji, jakie są użyte W metamodelu);

$\mathrm{Q} \subseteq \mathrm{E} \times \mathrm{E} \times \mathrm{T}^{*}-$ jest zbiorem relacji;

$\mathrm{F}_{\mathrm{c}}: \mathrm{E} \rightarrow \mathrm{C}$ - jest funkcją odwzorowującą elementy modelu na koncepty metamodelu.

Przy tak przyjętych definicjach model A

$$
\mathrm{A}=\left(\mathrm{E}, \mathrm{T}^{*}, \mathrm{Q}, \mathrm{F}_{\mathrm{c}}\right)
$$

jest zgodny z metamodelem M

wtedy i tylko wtedy, gdy

$$
\mathrm{M}=(\mathrm{C}, \mathrm{T}, \mathrm{R})
$$

$$
\forall \mathrm{t} \in \mathrm{T}^{*} \forall \mathrm{e} 1, \mathrm{e} 2 \in \mathrm{E}:(\mathrm{e} 1, \mathrm{e} 2, \mathrm{t}) \in \mathrm{Q} \Rightarrow\left(\mathrm{F}_{\mathrm{c}}\left(\mathrm{e}_{1}\right), \mathrm{F}_{\mathrm{c}}\left(\mathrm{e}_{2}\right), \mathrm{t}\right) \in \mathrm{R}
$$

Praktyczny przykład zależności między metamodelem a modelem architektonicznym przedstawia Rysunek 2 .
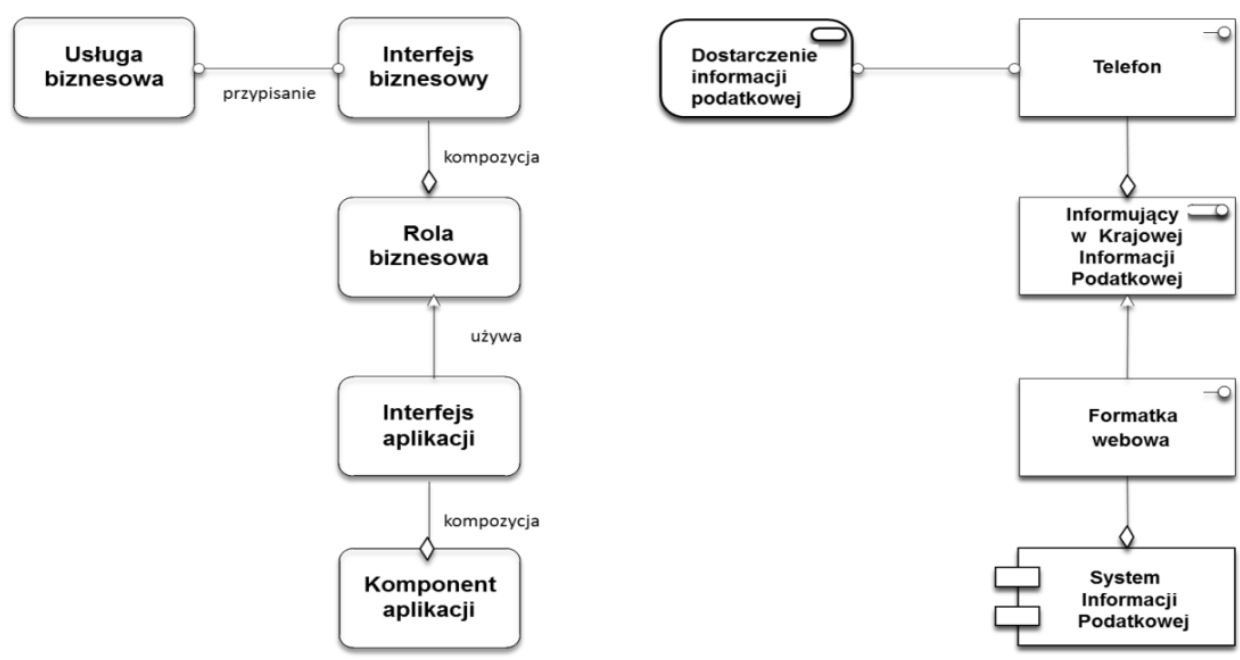

Rysunek 2. Fragment metamodelu (po prawej stronie) oraz odpowiadający mu model Źródło: opracowanie własne. (po lewej stronie) 
Na poziomie metamodelu występują takie byty jak: usługa biznesowa, interfejs biznesowy, rola biznesowa, interfejs aplikacji oraz aplikacja. Odpowiadają im następując obiekty na poziomie modelu: dostarczanie informacji podatkowej, telefon informujący w Krajowej Informacji Podatkowej, formatka webowa, system informacji podatkowej. Obiekty te są połączone (zgodnie z metamodelem) odpowiednio relacjami: przypisania, kompozycji oraz użycia.

\section{SKLADOWE METAMODELU ARCHITEKTURY KORPORACYJNEJ PAŃSTWA}

Na bazie wcześniejszych rozważań zdecydowano się opracować pilotażową wersję metamodelu architektury korporacyjnej państwa. Przy jego konstruowaniu przyjęto trzy istotne założenia. Po pierwsze ma on charakter generyczny tj. można go zastosować do budowy modeli architektonicznych dla dowolnego kraju Unii Europejskiej. Oznacza to, że w celu jego efektywnej implementacji niezbędne jest dopasowanie go do specyfiki danej administracji publicznej (dopasowanie takie powinno być „krokiem zerowym” budowy architektury korporacyjnej państwa). Drugie założenie dotyczyło poziomu architektonicznego objętego danym metamodelem. Zdecydowano się na dedykowanie go architekturze strategicznej. Jest to bowiem poziom, którego w największym stopniu brakuje w obecnie realizowanych przedsięwzięciach - szczególnie w warunkach polskich - w administracji publicznej (utrudnia to koordynację tych prac). Wreszcie przyjęto, że pilotażowa wersji metamodelu zawężona zostanie do elektronicznych usług publicznych ( $\mathrm{w}$ docelowej wersji możliwe jest uwzględnienie wszystkich rodzajów usług publicznych, świadczonych również kanałami tradycyjnymi).

Do stworzenia metamodelu zdecydowano się zastosować język UML w wersji 2.4. Zawartość metamodelu została opracowana na podstawie doświadczeń własnych autora związanych z uczestnictwem $w$ realizacji dużych programów transformacyjnych w polskim sektorze publicznym oraz prac nad pryncypiami architektury korporacyjnej państwa.

W niniejszej pracy zawarto szczegółową analizę poszczególnych elementów metamodelu. Każde pojęcie zostało opisane w taki sam sposób: nazwa pojęcia, jego definicja, relacje z innymi pojęciami. Dodatkowo na Rysunku 4. zostały umieszczone również liczności przy relacjach. Sposób dokumentowania relacji pomiędzy poszczególnymi elementami metamodelu przedstawia Tabela 1. 
Tabela 1. Sposób opisu relacji występujących w metamodelu architektury korporacyjnej państwa

\begin{tabular}{|c|c|c|c|}
\hline Relacja & Obiekt źródłowy & Obiekt docelowy & Opis relacji \\
\hline Typ relacji & nazwa obiektu źródłowego & nazwa obiektu docelowego & opis relacji \\
\hline
\end{tabular}

Źródło: opracowanie własne.

Przy tworzeniu metamodelu wykorzystano następujące typy relacji:

- Asocjacja - reprezentuje trwały związek pomiędzy elementami metamodelu; określenie „trwały” oznacza, że z biegiem czasu związek będzie pozostawał istotny, mimo że powiązania między wystąpieniami tych elementów mogą ulegać zmianie; na potrzeby niniejszego metamodelu zastosowano agregacje skierowane, przy czym w tym wypadku skierowanie ma jedynie charakter informacyjny, tj. wskazuje kierunek odczytu opisu asocjacji.

- Agregacja - specjalny rodzaj asocjacji, który służy do modelowania związku część-całość; używa się jej do pokazania silnego związku między bytami dziedziny problemowej.

- Dziedziczenie - związek występujący między bardziej ogólnym elementem (rodzicem) a bardziej szczegółowym elementem (dzieckiem) w pełni zgodnym z nadrzędnym i zawierającym ponadto dodatkowe informacje czy własności.

Poniżej przedstawiono ułożone alfabetycznie definicje poszczególnych elementów (bytów) składowych metamodelu. Zostały one specjalnie ustalone na potrzeby tego opracowania.

- Cel - formalnie ustalony powód, dla którego jest lub był wdrażany system informatyczny.

- Czynnik sterujący - podstawa do zdefiniowania celów dostarczenia (budowy) danego systemu informatycznego. Możliwe są następujące rodzaje czynnika sterującego: przepis prawa, regulacje unijne, czynnik wynikający ze strategii organizacji, uwarunkowanie społeczno-ekonomiczne, uwarunkowanie technologiczne.

- Dostawca technologii - podmiot, którego technologia jest dostarczana przy budowie/rozwoju danego systemu informatycznego.

- Grupa danych - pogrupowanie danych na określony temat istotny od strony merytorycznej.

- Kategoria systemu - rodzaj systemu informatycznego; dopuszcza się następujące wartości: system krytyczny dla funkcjonowania państwa, system standardowy z punktu widzenia funkcjonowania państwa, system pomocniczy z punktu widzenia funkcjonowania państwa.

- Kategoria użytkownika - rodzaj odbiorcy usługi publicznej on-line; dopuszcza się następujące wartości: osoba fizyczna, osoba prawna (przy czym dopuszcza się w tym przypadku następujące osoby prawne: przedsiębiorstwo, 
organizacja pozarządowa, jednostka sektora publicznego niebędąca urzędem, inna jednostka administracji publicznej).

- Miernik realizacji celu - stopień osiągnięcia realizacji danego celu.

- Obszar merytoryczny - kategoria merytoryczna związana z jedną lub większą liczbą usług publicznych on-line; przykładami obszaru merytorycznego mogą być: ochrona zdrowia, administracja podatkowa, służba zagraniczna itp.

- Przedsięwzięcie realizacyjne - projekt lub program w ramach którego tworzony jest lub rozwijany dany system informatyczny.

- System informatyczny - zbiór powiązanych ze sobą komponentów technicznych oraz organizacyjnych, którego funkcją jest przetwarzanie danych przy użyciu techniki komputerowej. System może składać się z podsystemów.

- Urząd - jednostka administracji publicznej, która jest właścicielem systemu informatycznego.

- Usługa publiczna on-line - usługa świadczona przez administrację publiczną otoczeniu zewnętrznemu z wykorzystaniem technologii internetowej.

- Wykonawca - podmiot wykonujący dane przedsięwzięcie realizacyjne (tworzący bądź rozwijający system informatyczny).

- Zasób informacyjny - pogrupowane według określonych reguł dane potrzebne do skutecznego podejmowania decyzji w danym obszarze merytoryczny mające postać cyfrową. Możliwe są dwa główne rodzaje zasobów informacyjnych: ewidencje oraz rejestry.

W Tabeli 2 przestawiono opis relacji występujących w metamodelu architektury korporacyjnej państwa.

Dla części bytów występujących na metamodelu zdefiniowano atrybuty - np. dla „miernika realizacji celu” określono atrybut „wartość oczekiwana”. Atrybuty te mają jedynie charakter przykładowy. Ich celem było przedstawienie możliwego kierunku uszczegółowiana metamodelu architektury korporacyjnej państwa. Zakłada się bowiem, że podczas rzeczywistej implementacji metamodelu architektury korporacyjnej państwa (czyli budowy modeli na bazie metamodelu) lista atrybutów zostanie rozbudowana o cechy specyficzne dla danej sytuacji.

Tabela 2. Opis relacji występujących w metamodelu architektury korporacyjnej państwa

\begin{tabular}{|c|c|c|c|l|}
\hline Relacja & $\begin{array}{c}\text { Obiekt źró- } \\
\text { dłowy }\end{array}$ & $\begin{array}{c}\text { Obiekt } \\
\text { docelowy }\end{array}$ & Nazwa relacji & \multicolumn{1}{|c|}{ Opis relacji } \\
\hline 1 & 2 & 3 & 4 & 5 \\
\hline Asocjacja & System & $\begin{array}{c}\text { Dostawca } \\
\text { technologii }\end{array}$ & $\begin{array}{c}\text { jest zrealizo- } \\
\text { wany w tech- } \\
\text { nologii dostar- } \\
\text { czonej przez }\end{array}$ & $\begin{array}{l}\text { Składowe systemu są zrealizowane } \\
\text { w co najmniej jednej lub większej } \\
\text { liczbie technologii dostarczanej } \\
\text { przez konkretnego producenta. } \\
\text { Dostawca technologii jest wyko- } \\
\text { rzystywany w co najmniej jednym } \\
\text { systemie. }\end{array}$ \\
\hline
\end{tabular}


Tabela 2 (cd.)

\begin{tabular}{|c|c|c|c|c|}
\hline 1 & 2 & 3 & 4 & 5 \\
\hline Asocjacja & System & $\begin{array}{l}\text { Usługa pu- } \\
\text { bliczna } \\
\text { on-line }\end{array}$ & świadczy & $\begin{array}{l}\text { System świadczy jedną usługę lub } \\
\text { większą liczbę usług publicznych } \\
\text { on-line. Usługa publiczna jest } \\
\text { świadczona przez jeden lub więk- } \\
\text { szą liczbę systemów. }\end{array}$ \\
\hline Agregacja & System & System & agreguje & $\begin{array}{l}\text { System może składać się z jednego } \\
\text { podsystemu lub większej ich } \\
\text { liczby. }\end{array}$ \\
\hline Asocjacja & System & System & jest połączony & $\begin{array}{l}\text { System może być połączony } \\
\text { z jednym systemem lub kilkoma } \\
\text { innymi systemami. }\end{array}$ \\
\hline Agregacja & $\begin{array}{l}\text { Kategoria } \\
\text { systemu }\end{array}$ & System & agreguje & $\begin{array}{l}\text { Kategoria systemu agreguje jeden } \\
\text { lub więcej systemów. System należy } \\
\text { dokładnie do jednej kategorii. }\end{array}$ \\
\hline Asocjacja & $\begin{array}{l}\text { Usługa } \\
\text { publiczna } \\
\text { on-line }\end{array}$ & $\begin{array}{l}\text { Usługa pu- } \\
\text { bliczna } \\
\text { on-line }\end{array}$ & jest połączona & $\begin{array}{l}\text { Usługa publiczna on-line może } \\
\text { być połączona z jedną usługą } \\
\text { publiczną lub kilkoma innymi } \\
\text { usługami. }\end{array}$ \\
\hline Agregacja & $\begin{array}{c}\text { Obszar } \\
\text { merytoryczny }\end{array}$ & $\begin{array}{l}\text { Usługa pu- } \\
\text { bliczna } \\
\text { on-line }\end{array}$ & agreguje & $\begin{array}{l}\text { Obszar merytoryczny agreguje } \\
\text { jedną usługę publiczną on-line lub } \\
\text { większą ich liczbę. Usługa należy } \\
\text { do jednego obszaru. }\end{array}$ \\
\hline Asocjacja & Urząd & System & $\begin{array}{c}\text { jest } \\
\text { właścicielem }\end{array}$ & $\begin{array}{l}\text { Urząd może być właścicielem } \\
\text { jednego lub więcej systemów. } \\
\text { System ma jednego właściciela. }\end{array}$ \\
\hline Asocjacja & $\begin{array}{l}\text { Usługa } \\
\text { publiczna } \\
\text { on-line }\end{array}$ & $\begin{array}{c}\text { Kategoria } \\
\text { użytkownika }\end{array}$ & $\begin{array}{c}\text { jest } \\
\text { świadczona } \\
\text { dla }\end{array}$ & $\begin{array}{l}\text { Usługa publiczna on-line jest } \\
\text { świadczona dla jednej lub więk- } \\
\text { szej liczby kategorii użytkowni- } \\
\text { ków. }\end{array}$ \\
\hline Asocjacja & $\begin{array}{l}\text { Przedsię- } \\
\text { wzięcie reali- } \\
\text { zacyjne }\end{array}$ & System & dostarcza & $\begin{array}{l}\text { W ramach przedsięwzięcia reali- } \\
\text { zacyjnego (typy projekt/program) } \\
\text { dostarczany jest system informa- } \\
\text { tyczny. }\end{array}$ \\
\hline Asocjacja & Wykonawca & Wykonawca & $\begin{array}{c}\text { jest związany } \\
\text { z }\end{array}$ & $\begin{array}{l}\text { Wykonawca systemu może być } \\
\text { związany (kapitało- } \\
\text { wo/organizacyjnie) z innymi } \\
\text { wykonawcami. }\end{array}$ \\
\hline Asocjacja & Wykonawca & $\begin{array}{l}\text { Przedsię- } \\
\text { wzięcie } \\
\text { realizacyjne }\end{array}$ & realizuje & $\begin{array}{l}\text { Wykonawca realizuje jedno przed- } \\
\text { sięwzięcie realizacyjne lub więk- } \\
\text { szą ich liczbę. Przedsięwzięcie jest } \\
\text { realizowane przez jednego lub } \\
\text { kilku wykonawców. }\end{array}$ \\
\hline Dziedziczenie & $\begin{array}{c}\text { Kategoria } \\
\text { użytkownika }\end{array}$ & Urząd & dziedziczy & $\begin{array}{l}\text { Urząd jest szczególnego rodzaj } \\
\text { kategorią użytkownika elektro- } \\
\text { nicznej usługi on-line. }\end{array}$ \\
\hline Asocjacja & System & Cel & realizuje & $\begin{array}{l}\text { System realizuje jeden cel lub } \\
\text { więcej. Cel jest realizowany przez } \\
\text { jeden system lub większą ich } \\
\text { liczbę. }\end{array}$ \\
\hline
\end{tabular}


Tabela 2 (cd.)

\begin{tabular}{|c|c|c|c|c|}
\hline 1 & 2 & 3 & 4 & 5 \\
\hline Asocjacja & $\begin{array}{c}\text { Miernik } \\
\text { realizacji celu }\end{array}$ & Cel & mierzy & $\begin{array}{l}\text { Miernik realizacji celów mierzy } \\
\text { stopień realizacji danego celu. } \\
\text { Jeden cel może mieć określony } \\
\text { jeden lub większą liczbę mierni- } \\
\text { ków. }\end{array}$ \\
\hline Asocjacja & $\begin{array}{l}\text { Czynnik } \\
\text { sterujący }\end{array}$ & Cel & $\begin{array}{l}\text { jest podstawą } \\
\text { zdefiniowania }\end{array}$ & $\begin{array}{l}\text { Czynnik sterujący jest podstawą } \\
\text { zdefiniowania celu lub celów } \\
\text { realizacji systemów. Wyróżnia się } \\
\text { następujące rodzaje czynników: } \\
\text { przepis prawa, regulacja unijna, } \\
\text { cele organizacji, uwarunkowania } \\
\text { społeczno-ekonomiczne, uwarun- } \\
\text { kowania technologiczne; cele te są } \\
\text { realizowane za pomocą jednego } \\
\text { systemu lub większej ich liczby. }\end{array}$ \\
\hline Asocjacja & Urząd & $\begin{array}{c}\text { Zasób } \\
\text { informacyjny }\end{array}$ & $\begin{array}{c}\text { jest } \\
\text { właścicielem }\end{array}$ & $\begin{array}{l}\text { Urząd może być właścicielem } \\
\text { jednego lub większej liczby zaso- } \\
\text { bów informacyjnych. Wyróżnia } \\
\text { się dwa główne rodzaje zasobów: } \\
\text { ewidencje i rejestry; zasób ma } \\
\text { jednego właściciela. }\end{array}$ \\
\hline Agregacja & $\begin{array}{c}\text { Zasób } \\
\text { informacyjny }\end{array}$ & $\begin{array}{l}\text { Grupa } \\
\text { danych }\end{array}$ & agreguje & $\begin{array}{l}\text { Zasób informacyjny agreguje } \\
\text { jedną grupę danych lub większą } \\
\text { ich liczbę. }\end{array}$ \\
\hline
\end{tabular}

Źródło: opracowanie własne.

Pilotażowy metamodel architektury korporacyjnej państwa liczy 23 byty. Przy czym w celu zachowania jego elastyczności każdy z bytów metamodelu ma przypisany atrybut „obowiązkowość”. Przyjmuje on wartości „tak” oraz „nie”. Bytów, dla których atrybut „obowiązkowość” przyjął wartość „tak”, jest łącznie siedem (są to: system, urząd, usługa publiczna on-line, zasób informacyjny, kategoria użytkownika, osoba fizyczna, osoba prawna). Stworzenie modeli z wykorzystaniem tych bytów pozwoli zebrać podstawowe (fundamentalne) informacje o architekturze korporacyjnej państwa. Dodatkowo pozostałe byty zostały zaklasyfikowane do jednego z kilku rozszerzeń (por. Rysunek 3):

- Rozszerzenie nakierowane na dane (obejmuje następujące byty: rejestr, ewidencja, grupa danych) - jego wykorzystanie pozwoli opisać zagadnienia związane z przetwarzaniem danych.

- Rozszerzenie dotyczące implementacji (obejmuje następujące byty: dostawca technologii, przedsięwzięcie realizacyjne, wykonawca) - jego wykorzystanie pozwoli opisać zagadnienia związane ze sposobem dostarczania systemów opisanych w ramach architektury korporacyjnej państwa. 
- Rozszerzenie dotyczące motywacji (obejmuje następujące byty: cel, miernik realizacji celu, czynnik sterujący, przepis prawa, regulacja unijna, cele organizacji, uwarunkowania społeczno-ekonomiczne, uwarunkowania technologiczne) - jego wykorzystanie pozwoli opisać zagadnienia związane z motywacją będącą podstawą realizacji poszczególnych systemów, opisanych w ramach architektury korporacyjnej państwa.

- Rozszerzenie klasyfikacyjne (obejmuje następujące byty: kategoria systemu, obszar merytoryczny) - jego wykorzystanie pozwoli dokonać klasyfikacji systemów opisanych w ramach architektury korporacyjnej państwa.

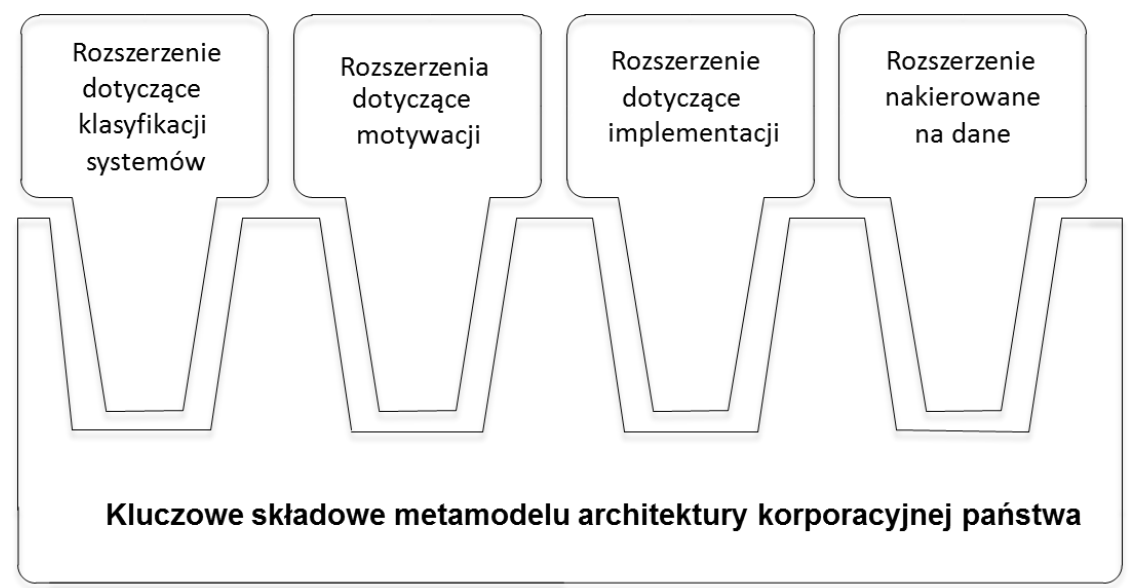

Rysunek 3. Podział bytów składowych metamodelu architektury państwa na kluczowe (obowiązkowe) i dodatkowe

Źródło: opracowanie własne.

Tworząc modele architektoniczne, można wybrać i zastosować jedno lub kilka z powyższych rozszerzeń. Konsekwencją wprowadzenia większej liczby rozszerzeń jest jednak zdecydowany wzrost złożoności modeli architektonicznych, a co za tym idzie zdecydowanie większe koszty ponoszone na ich zbudowanie $i$ aktualizację.

Istotnym elementem upraszczającym prezentację graficzną metamodelu jest pominięcie na Rysunku 4. zagnieżdżeń (rekurencji) poszczególnych bytów. Domyślnie przyjmuje się, że każdy element metamodelu może zostać zdekomponowany, np. cel na cele podrzędne, system na podsystemy, urząd na jednostki składowe urzędu. 


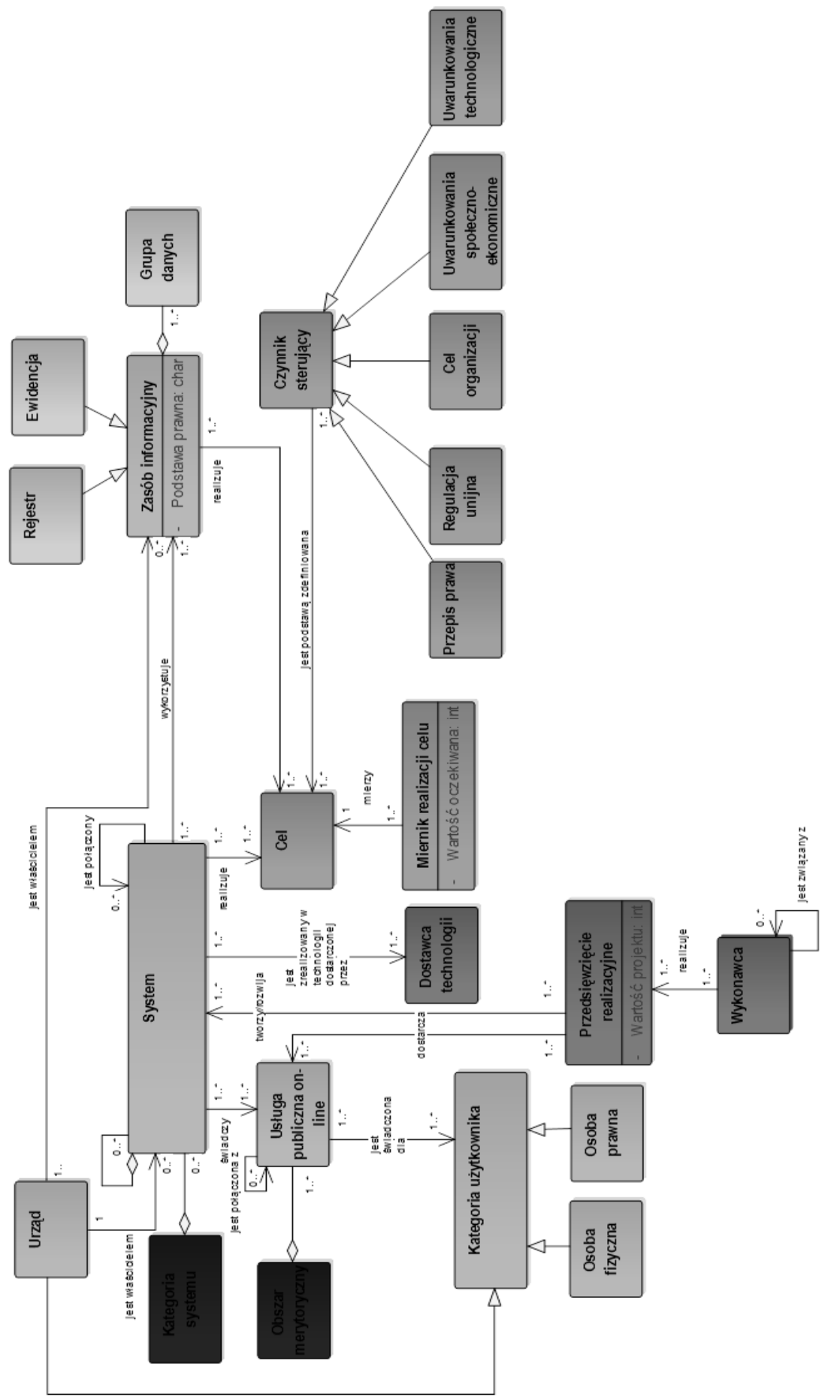

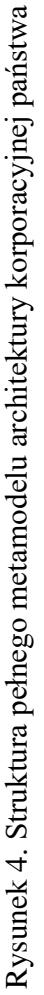

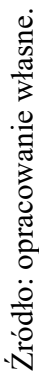


Zdefiniowany $\mathrm{w}$ niniejszym punkcie pilotażowy metamodel architektury korporacyjnej państwa może być nie tylko podstawą do usprawnienia komunikacji między interesariuszami zaangażowanymi $\mathrm{w}$ zastosowanie podejścia architektonicznego w sektorze publicznym, ale też może stanowić punkt wyjścia do określenia struktury repozytorium architektonicznego przechowującego wiedzę architektoniczną na temat sposobu funkcjonowania administracji publicznej danego kraju (zarówno na poziomie organizacyjnym, jak i technologicznym).

\section{PODSUMOWANIE I KIERUNKI DALSZYCH BADAŃ}

Do niedawna w polskich warunkach barierę w wykorzystaniu koncepcji architektury korporacyjnej państwa stanowiły kwestie finansowe. W grudniu 2014 r. Komisja Europejska zaakceptowała Program Operacyjny Polska Cyfrowa na lata 2014-2020. Jego celem jest wzmocnienie cyfrowych fundamentów dla rozwoju kraju poprzez: zapewnienie szerokiego dostępu do szybkiego internetu, zbudowanie efektywnych i przyjaznych użytkownikom e-usług publicznych oraz stałe zwiększanie poziomu kompetencji cyfrowych społeczeństwa. Budżet programu wynosi blisko 2,2 mld EUR (środki unijne). W praktyce oznacza to, że w najbliższych latach nie wystąpią ograniczenia finansowe w zakresie budowy cyfrowego państwa. Pojawiło się natomiast inne wyzwanie dotyczące możliwości racjonalnego wykorzystania tych środków.

Innym utrudnieniem we wdrożeniu architektury korporacyjnej państwa są kompetencje i podejście dostawców technologicznych. Obecnie większość z nich patrzy na informatyzację państwa jedynie z perspektywy wdrożenia konkretnego rozwiązania technologicznego. Dlatego w większości przypadków nie są oni zainteresowani podjęciem dialogu z przedstawicielami administracji na temat całościowego funkcjonowania państwa. Nie dążą również do znalezienia optymalnej ścieżki osiągnięcia pożądanych rezultatów.

Wydaje się jednak, że największą przeszkodę w realizacji architektury korporacyjnej w Polsce stanowią kwestie mentalne. W szczególności jest to występujący po stronie urzędników opór, ponieważ większość z nich nie jest przystosowana do funkcjonowania w cyfrowym środowisku, a takie jest kreowane $\mathrm{w}$ ramach inicjatyw związanych z zastosowaniem podejścia architektonicznego.

Jednocześnie urzędy administracji publicznej mogą i powinny wymieniać między sobą dobre wzorce $\mathrm{w}$ zakresie realizacji działań architektonicznych. Zyskać na tym mogą przede wszystkim te urzędy, w których poziom dojrzałości w zakresie zarządzania realizacją złożonych przedsięwzięć (w tym projektów i programów z obszaru cyfrowej transformacji) jest niski.

Zaprezentowany w niniejszym artykule autorski pilotażowy metamodel architektury korporacyjnej państwa może stanowić podstawę do podjęcia współ- 
pracy i wymiany doświadczeń w realizacji koncepcji architektonicznych w sektorze publicznym. Niezbędne są jednakże dalsze prace metodyczne i weryfikacyjne w zakresie tego podejścia. Autor ma świadomość, że obecna wersja metamodelu ma pewne ograniczenia. Przyjęto np. założenie, że koncentracja nastąpi na usługach publicznych on-line, a nie na wszystkich rodzajach usług. Dodatkowo uwzględniono w nim przede wszystkim uwarunkowania polskiej administracji publicznej, a nie dowolnej administracji publicznej. Dlatego w przyszłości planuje się uzupełnienie i rozbudowę metamodelu o kolejne składowe (tym bardziej, że - jak wskazano w punkcie 2. artykułu - architektura korporacyjna państwa ma bardzo szeroki obszar zastosowań nieograniczający się jedynie do koordynacji cyfrowej transformacji). Dodatkowo zakłada się zbudowanie pilotażowego repozytorium architektonicznego, w ramach którego zaimplementowany zostanie opracowany metamodel.

\section{BIBLIOGRAFIA}

Day-Yang L., Shou-Wei C., Tzu-Chuan Chou C. (2011), Resource fit in digital transformation: Lessons learned from the CBC Bank global e-banking project, "Management Decision", vol. 49, nr 10, s. 1728-1742.

Gutenbaum J. (2003), Modelowanie matematyczne systemów, Akademicka Oficyna Wydawnicza Exit, Warszawa.

Kaisler S., Armour F., Valivullah M. (2005), Enterprise Architecting: Critical Problems, Proceedings of the $38^{\text {th }}$ Hawaii International Conference on System Sciences, 03-06 January 2005, Hawaje.

Khoury G., Simoff S., Debenham J. (2005), Modelling Enterprise Architectures: An Approach Based on Linking Metaphors and Ontologies, Proceedings of The Australasian Ontology Workshop AOW 2005, Sydney.

Kisielnicki J. (1993), Informatyczna infrastruktura zarzadzania, Wyd. Nauk. PWN, Warszawa.

Lapalme J. (2011), 3 Schools of Enterprise Architecture, "IT Professional" 2011, vol. PP, nr 99, s. 37-43.

Liang P., Jansen A., Avgeriou P. (2009), Sharing architecture knowledge through models: quality and cost, "The Knowledge Engineering Review" vol. 24, nr 3, s. 225-244.

MSWiA (2011), Rozporządzenie Rady Ministrów w sprawie Planu Informatyzacji Państwa do roku 2015.

Object Management Group (2004), The Meta Object Facility Specification 2.0.

Sobczak A. (2013), Architektura korporacyjna. Aspekty teoretyczne i wybrane zagadnienia praktyczne, Fundacja Ośrodek Studiów nad Cyfrowym Państwem, Łódź.

Sobczak A. (2015), Metodyczne aspekty opracowywania architektury korporacyjnej państwa, Roczniki Kolegium Analiz Ekonomicznych, Oficyna Wydawnicza Szkoły Głównej Handlowej w Warszawie, Warszawa, s. 220-245. 
Andrzej Sobczak

\section{METAMODEL OF NATIONAL ENTERPRISE ARCHITECTURE}

Abstract. In order to effectively carry out digital transformation of the state is necessary to use the correct methodology tools. One of the tools to support the conduct of this transition can be a state enterprise architecture. This article attempts to define this concept and presents the author's metamodel allowing for uniform application of the concepts used for architectural diagrams. This makes it possible to build a consistent description of the state in terms of architecture.

Keywords: Enterprise Architecture, National Enterprise Architecture, Architecture Metamodel, Architecture Models, Metamodel for National Enterprise Architecture. 